\title{
ANALISIS RISIKO USAHATANI PADI PADA LAHAN PASANG SURUT DI KABUPATEN PONTIANAK
}

\author{
Muhammad Zakirin*, Erlinda Yurisinthae**, Novira Kusrini ${ }^{* *}$ \\ *Mahasiswa MMA Fakultas Pertanian Universitas Tanjungpura Pontianak \\ ** Staf Pengajar Fakultas Pertanian Universitas Tanjungpura Pontianak
}

\begin{abstract}
ABSTRAK
Risiko usahatani dapat disebabkan oleh faktor lingkungan agroekologi, faktor input, dan manajemen. Kajian ini bertujuan untuk (a) menganalisis faktor-faktor yang mempengaruhi produksi dalam usahatani padi di lahan pasang surut, (b) menganalisis beda resiko produksi padi di lahan pasang surut pada tipe luapan yang berbeda, dan (c) menganalisis faktor-faktor yang mempengaruhi risiko produksi padi di lahan pasang surut.

Jumlah sampel yang digunakan dalam penelitian ini adalah 75 rumah tangga yang dipilih dengan metode simple random sampling. Analisis data menggunakan regresi liner berganda dengan model fungsi produksi cobb-douglas dan fungsi produksi just and pope. Selain itu juga digunakan analisis one way anova. Hasil penelitian menunjukkan bahwa (a) Faktorfaktor yang mempengaruhi produksi padi adalah Iahan, benih, Urea, herbisida, tenaga kerja, umur petani, dan dummy tipe luapan B. Setiap penambahan luas lahan 1 persen akan menambah produksi padi 0.0342 persen. Setiap penambahan benih 1 persen akan diikuti kenaikan produksi padi 0,1054 persen. Setiap kenaikan Urea 1 persen akan menaikkan produksi padi 0.0576 persen. Setiap bertambahnya herbisida 1 persen akan diikuti peningkatan produksi padi 0.0825 persen. Setiap peningkatan tenaga kerja 1 persen akan menaikkan produksi 0.0165 persen. Semakin bertambah umur petani sampai batas tertentu (periode usia produktif) produksi padi semakin meningkat. Produksi padi di lahan tipe B berbeda nyata (lebih tinggi) dengan tipe luapan yang lain (A dan C); (b) Berdasarkan uji LSD, risiko produksi pada tipe B lebih rendah dibanding tipe A. Sedangkan risiko produksi tipe $C$ tidak berbeda dengan tipe A dan tipe B. Berdasarkan nilai standar deviasi, risiko produksi paling tinggi pada tipe $A$ diikuti tipe $C$, dan tipe $B$, atau dengan kata lain tipe $B$ mempunyai rlsiko produksi paling rendah; (c) Faktor-faktor yang mempengaruhi risiko produksi padi adalah lahan dan benih dengan pengaruh negatif. Setiap penambahan luas lahan sebesar 1 persen akan menurunkan risiko produksi padi sebesar 1.1126 persen. Setiap penambahan benih sebesar 1 persen akan diikuti penurunan risiko produksi padi sebesar 1.7244 persen.
\end{abstract}

Kata Kunci: produksi, usahatani, resiko, padi, tipe luapan, pasang surut.

\section{PENDAHULUAN}

Dalam berbagai kegiatan usaha di bidang pertanian sering terjadi situasi ekstrim, yaitu kejadian yang mengandung risiko (risk events) dan kejadian yang tidak pasti (uncertainty events). Risiko produksi pertanian lebih besar dibandingkan risiko non pertanian, karena pertanian sangat dipengaruhi oleh alam seperti cuaca, hama penyakit, suhu, kekeringan, dan banjir. Selain alam, risiko dapat ditimbulkan oleh kegiatan pemasaran. Risiko harga disebabkan karena harga pasar tidak dapat dikuasai petani. Fluktuasi harga lebih sering terjadi pada hasil-hasil pertanian.

Menurut Widodo (2006:4) risiko dapat bersumber pada siklus bisnis, fluktuasi musiman, inflasi, iklim, hama penyakit, nilai tukar rupiah, dan teknologi. Sementara itu menurut Kay (1981) sumber risiko dan ketidakpastian bidang pertanian diantaranya adalah 
production and technical risk yaitu risiko produksi yang terjadi oleh adanya hubungan teknis antara output dan tingkat penggunaan input, harga, finansial, kebijakan pemerintah, dan individu.

Wilayah Kalimantan Barat seluas 14,680.700 hektar, yang terdiri dari lahan kering 3.012.814 hektar (20,49\%); lahan pasang surut (rawa) seluas 1.904 .100 hektar $(12,95 \%)$, gambut 1.677 .550 hektar $(11,41 \%)$, lahan non pasang surut 18.750 hektar $(0,13 \%)$ Lahan perairan seluas 8.273 hektar dan lainnya adalah lahan pegunungan (BPS Kalbar, 2007).

Luas lahan pasang surut di Kalimantan Barat adalah 1.904 .100 ha atau 12,95\% dari total luas wilayah $(14,680.700 \mathrm{ha})$. Lahan pasang surut merupakan lahan marginal yang dicirikan adanya permasalahan keracunan pirit, interusi air laut, salinitas, sehingga produktifitasnya rendah.

Hasil studi Herawati et al (1993) di kawasan ISDP Kalimantan Barat menunjukkan bahwa lahan potensial dan lahan sulfat masam kebanyakan memiliki tipe luapan A dan B, sedangkan untuk lahan gambut dan bergambut memiliki tipe luapan B dan C. Pada umumnya penataan lahan pada tipologi potensial dengan tipe luapan A adalah sawah, untuk tipe luapan B agak beragam yaitu sawah dan surjan. Untuk lahan sulfat masam dengan tipe luapan A adalah sawah. Untuk lahan bergambut tipe luapan B sebagian besar adalah surjan dan sebagian kecil sawah. Untul lahan bergambut tipe luapan $\mathrm{C}$ adalah sawah tadah hujan, surjan dan tegalan.

Usahatani pada agroekologi pasang surut mempunyai risiko yang relatif tinggi, mengingat lahan pasang surut merupakan lahan marjinal dengan berbagai masalah yang ada. Faktor risiko juga dapat disebabkan serangan hama dan penyakit, bencana alam, iklim yang kurang menguntungkan, fluktuasi harga, dan sosial ekonomi petani menyebabkan terjadinya senjang produktivitas. Dampak ketidakpastian hasil panen akan mengakibatkan produsen enggan memasuki pasar produksi. Pengaruh perilaku demikian akan menyebabkan senjang produktivitas

Adapun tujuan penelitian ini adalah (a) menganalisis faktor-faktor yang mempengaruhi produksi dalam usahatani padi di lahan pasang surut, (b) menganalisis beda resiko produksi padi di lahan pasang surut pada tipe luapan yang berbeda, dan (c) menganalisis faktor-faktor yang mempengaruhi risiko produksi padi di lahan pasang surut. Adapun manfaat yang diharapkan dari penelitian ini adalah dapat mewujudkan kebijakan pengembangan usahatani padi yang diarahkan pada peningkatan produktivitas dan pendapatan dengan mempertimbangkan aspek risiko.

\section{METODE}

Penelitian ini dilakukan dengan menggunakan metode deskriptif analitis, yaitu suatu metode penelitian yang memusatkan perhatian pada pemecahan masalah yang terjadi pada masa sekarang, pada masalah yang aktual. Data yang telah dikumpulkan mula-mula disusun, dijelaskan, kemudian dianalisis (Surachmad, 1988). Penelitian ini dilakukan di Kabupaten Pontianak yang difokuskan di beberapa kecamatan yang memiliki agroekologi pasang surut, seperti Kecamatan Siantan, Sungai Pinyuh, Mempawah Hilir, dan Sui Kunyit. Adapun waktu penelitian dilakukan mulai bulan Agustus 2011 sampai dengan selesai.

Jumlah sampel yang digunakan dalam penelitian ini adalah 75 rumah tangga tani yang tersebar di daerah pasang surut dengan berbagai tipe luapan dan tipologi lahan. Teknik pengambilan sampel lokasi dilakukan dengan menggunakan teknik purpossive sampling. Menurut Pasaribu (1983); Hermawan (2005); Suratno dan Arsyad (1999), pengertian 
purposive sampling adalah memilih sampel secara sengaja dengan pertimbanganpertimbangan khusus atau berdasarkan kriteria tertentu yang dimiliki sample tersebut. Sedangkan pengambilan sampel petani di masing-masing lokasi menggunakan simple random sampling. Menurut Hermawan (2005), dan Supranto (1997), simple random sampling merupakan prosedur penarikan sample yang memungkinkan setiap elemen dalam populasi memiliki peluang yang sama untuk dijadikan sample.

\section{Metode Analisis dan Pengujian Hipotesis}

Hipotesis 1. Diduga produksi padi di lahan pasang surut dipengaruhi oleh penggunaan lahan, benih, urea, SP36, $\mathrm{KCl}$, herbisida, pestisida, tenaga kerja, pendidikan, umur, dan tipe luapan

Untuk menguji hipotesis tersebut digunakan analisis model fungsi produksi tipe CobbDouglas dengan model analisis sebagai berikut :

$\operatorname{Ln} Y=\ln \alpha+\beta_{1} \ln \mathrm{LHN}+\beta_{2} \ln \mathrm{BNH}+\beta_{3} \ln \mathrm{UREA}+\beta_{4} \operatorname{In} \mathrm{SP}+\beta_{5} \ln \mathrm{KCl}+\beta_{6} \ln \mathrm{HERB}+\beta_{7} \operatorname{In}$ PEST $+\beta_{8} \ln$ TNG $++\beta_{9} \ln$ UMUR $+\beta_{10} \ln \mathrm{PDDK}+\beta_{11} \mathrm{D} 1+\beta_{12} \mathrm{D} 2+\varepsilon$

Keterangan

$\mathrm{Y}=$ Produktivitas padi $(\mathrm{kg} / \mathrm{ha} / \mathrm{musim})$

$\alpha=$ Intersept

$\beta_{\mathrm{i}} \quad=$ koefisien regresi (parameter yang ditaksir) $(i=1 \mathrm{~s} / \mathrm{d} 9)$

סi $\quad=\quad$ koefisien variabel dummy (parameter yang ditaksir) $(i=1 \mathrm{~s} / \mathrm{d} 2)$

$\varepsilon=$ error term/disturbance error/pengganggu

$\mathrm{LHN}=$ lahan (ha)

$\mathrm{BNH}=\operatorname{benih}(\mathrm{kg} / \mathrm{ha} /$ musim $)$

UREA = Urea $(\mathrm{kg} / \mathrm{ha} /$ musim $)$

$\mathrm{SP}=\mathrm{SP} 36(\mathrm{~kg} / \mathrm{ha} / \mathrm{musim})$

$\mathrm{KCl}=\mathrm{KCl}(\mathrm{kg} / \mathrm{ha} /$ musim $)$

HERB = pestisida (liter/ha/musim)

PEST = tenaga kerja $(\mathrm{HOK} /$ ha/musim $)$

UMUR = umur petani (tahun)

PDDK = pendidikan (tahun)

D1 = Tipe luapan $B, D 1=1$ tipe lupan $B, D 1=0$ tipe luapan lain

D2 = Tipe luapan C, D2=1 tipe lupan $\mathrm{C}, \mathrm{D} 2=0$ tipe luapan lain

(Tipe luapan A untuk kontrol)

Untuk memperoleh validitas, dilakukan uji penyimpangan asumsi klasik dan uji kesesuaian model (Pindyck and Rubinfeld, 1991; Gujarati, 1997). Uji asumsi klasik ditujukan untuk mengetahui apakah estimator merupakan penaksir tak bias terbaik (Best Linear Unbiased Estimator/BLUE). Dalam penelitian ini menggunakan data cross section maka perlu dilakukan uji asumsi klasik, yaitu non-multikolinearitas dan homoskedastisitas. Ruang lingkup dalam pengujian analisis inferensial adalah Koefisien determinasi $\left(R^{2}\right)$, Uji $F$ (over all test), dan Uji terhadap penduga parameter ( $t$ test $)$. 
Hipotesis 2. Risiko produksi padi di lahan pasang surut pada berbagai tipe luapan adalah berbeda.

Untuk menganalisis beda risiko produksi dapat digunakan one-way anova. Data yang dianalisis adalah data risiko produksi (bukan data produksi), sehingga sebelum analisis oneway anova ini dilakukan terlebih dahulu harus memperoleh data risiko produksi yang diperoleh dengan metode oleh Just and Pope (1974), yaitu:

1. Mengestimasi fungsi produksi cobb-douglas dengan metode Non Linear Least Square (NLS) sehingga diperoleh disturbance error sebagai proxy dari risiko produksi.

$Y=\mathbf{e}^{(\operatorname{In} \alpha+\beta 1 \ln L H N+\beta 2 \ln B N H+\beta 3 \ln \text { UREA }+\beta 4 \ln S P+\beta 5 \ln \mathrm{KCl}+\beta 6 \ln \mathrm{HERB}+\beta 7 \ln \mathrm{PEST}+\beta 8 \ln \mathrm{TNG})}+\boldsymbol{\epsilon}_{1}$

2. Selanjutnya disturbance error/ $\varepsilon_{1}$ (proxy dari resiko produksi) pada masing-masing tipe luapan tersebut dianalisis dengan one-way anova.

Hipotesis statistik untuk hipotesis. 2 yang diajukan adalah sebagai berikut:

Ho : $\sigma^{2}=0$, tidak ada perbedaan risiko produksi pada berbagai tipe luapan

Ha : $\sigma^{2} \neq 0$, ada perbedaan risiko produksi pada berbagai tipe luapan

Kaidah Keputusan Pengujian :

Jika $F_{\text {hitung }}>F_{\text {tabel, }}$ maka Ho ditolak, artinya ada perbedaan risiko produksi pada berbagai tipe luapan, sebaliknya jika $F_{\text {hitung }} \leq F_{\text {tabel, }}$ maka Ho diterima, artinya tidak ada perbedaan risiko produksi pada berbagai tipe luapan. Bila kaidah keputusan pengujian ini menghasilkan Ho ditolak atau Ha diterima, maka dilanjutkan dengan uji LSD (Least Significant Different) pada taraf $5 \%$ untuk mengetahui beda resiko produksi.

Hipotesis 3: Diduga resiko produksi dipengaruhi oleh penggunaan lahan, benih, urea, SP36, $\mathrm{KCl}$, herbisida, pestisida, tenaga kerja, pendidikan, umur petani.

Untuk menguji hiptosis ini, digunakan metode just and Pope (1974), dengan tahapan sebagai berikut:

1. Mengestimasi fungsi produksi cobb-douglas dengan metode Non Linear Least Square

$(\mathrm{NLS})$ sehingga diperoleh disturbance error $(\varepsilon 1)$ sebagai proxy dari risiko produksi.

$Y=e^{(\ln \alpha+\beta 1 \ln \mathrm{LHN}+\beta 2 \ln \mathrm{BNH}+\beta 3 \ln \mathrm{UREA}+\beta 4 \ln \mathrm{SP}+\beta 5 \ln \mathrm{KCl}+\beta 6 \ln \mathrm{HERB}+\beta 7 \ln \mathrm{PEST}+\beta 8 \ln \mathrm{TNG})}+\epsilon 1$

2. Selanjutnya distrubance error/risiko produksi tersebut di regress terhadap variabel bebas dengan metode Ordinary Least Square/OLS.

$\operatorname{Ln}\left|\varepsilon_{1}\right|=\ln \alpha+\beta_{1} \ln \mathrm{LHN}+\beta_{2} \ln \mathrm{BNH}+\beta_{3} \ln \mathrm{UREA}+\beta_{4} \ln \mathrm{SP}+\beta_{5} \ln \mathrm{KCl}+\beta_{6} \ln \mathrm{HERB}+$ $\beta_{7} \ln \mathrm{PEST}+\beta_{8} \ln \mathrm{TNG}+\beta_{9} \ln \mathrm{UMUR}+\beta_{10} \ln \mathrm{PDDK}+\epsilon_{2}$

Untuk memperoleh validitas hasil pengujian ekonometrik Model OLS, dilakukan uji asumsi klasik dan terhadap kesesuaian model seperti pada fungsi produksi.

\section{HASIL DAN PEMBAHASAN}

\section{Faktor-Faktor yang Mempengaruhi Produksi Padi di Lahan Pasang Surut}

Sebelum melakukan uji statistik terhadap hasil regresi, terlebih dahulu dilakukan uji multicollinierity. Gudjarati (1995) menyatakan bahwa multikolinearitas adalah hubungan linear yang sempurna atau pasti di antara beberapa atau semua variabel bebas. Untuk mengetahui gejala multicollinierity dapat diamati dari nilai Variance Inflation Factor (VIF). 
Menurut Soemartini (2008) jika nilai nilai VIF>10 maka multikolinearitas adalah masalah yang pasti terjadi antar variable bebas. Hasil analisis multicolinierity menunjukkan bahwa nilai VIF untuk semua variabel dibawah 10, artinya tidak ada gejala multicollinierity di antara variabel-variabel bebas.

Untuk mengetahui gejala heteroscedasticity dapat ketahui dari beberapa uji yaitu White, Breusch-Pagan-Godfrey, Harvey, dan Glejser. Dari hasil analisis diketahui bahwa dalam model regresi yang digunakan terdapat gejala heteroscedasticity. Untuk mengatasi adanya gejala heteroscedasticity digunakan metode White heteroskedasticity-consistent standard errors \& covariance. Hasil analisis regresi yang bebas gejala multicolinearity dan heteroscedasticity dapat dilihat pada tabel 1.

Berdasarkan nilai koefisien determinasi $\left(R^{2}\right)$ dapat diketahui bahwa variabel luas lahan, benih, Urea, SP36, KCl, jumlah herbisida, jumlah pestisida, tenaga kerja, umur petani, pendidikan petani, dummy tipe luapan (D1,D2) dapat menjelaskan 93,81\% terhadap variabel produksi padi. Variabel produksi padi yang tidak dapat dijelaskan oleh variabel-variabel bebas tersebut sebesar $6,19 \%$. Hal ini disebabkan oleh faktor lain yang tidak masuk dalam model. Berdasarkan nilai koefisien determinasi $\left(\mathrm{R}^{2}\right)$ ini dapat diketahui bahwa model yang digunakan cukup baik dalam menduga parameter dalam fungsi produksi.

Tabel 1. Faktor-faktor yang mempengaruhi produksi padi di lahan pasang surut Kabupaten Pontianak (bebas gejala multicolinearity dan heteroscedasticity)

\begin{tabular}{|c|c|c|c|c|}
\hline Variable & Coefficient & Std. Error & t-Statistic & Prob. \\
\hline $\mathrm{LHN}^{* * *}$ & 0.034188 & 0.011237 & 3.042476 & 0.0034 \\
\hline $\mathrm{BNH}^{* * *}$ & 0.105389 & 0.028307 & 3.723107 & 0.0004 \\
\hline UREA $A^{* \star *}$ & 0.057636 & 0.010947 & 5.265248 & 0.0000 \\
\hline SP36 & -0.000417 & 0.001589 & -0.262314 & 0.7939 \\
\hline $\mathrm{KCL}$ & -0.000301 & 0.002127 & -0.141727 & 0.8878 \\
\hline $\mathrm{HERB}^{\star \star \star *}$ & 0.082463 & 0.020147 & 4.092985 & 0.0001 \\
\hline PEST & -0.009153 & 0.006543 & -1.398916 & 0.1668 \\
\hline $\mathrm{TNG}^{*}$ & 0.016483 & 0.008984 & 1.834604 & 0.0714 \\
\hline UMUR $^{\star \star *}$ & 0.104305 & 0.035444 & 2.942789 & 0.0046 \\
\hline PDDK & 0.006490 & 0.010556 & 0.614769 & 0.5410 \\
\hline D1 (tipe B) $)^{\star \star *}$ & 0.025354 & 0.009336 & 2.715753 & 0.0086 \\
\hline D2 (tipe C) & 0.003929 & 0.009214 & 0.426413 & 0.6713 \\
\hline$C^{* * *}$ & 6.715570 & 0.160258 & 41.90484 & 0.0000 \\
\hline R-squared & 0.938098 & \multicolumn{2}{|l|}{ Mean dependent var } & 7.916133 \\
\hline Adjusted R-squared & 0.926117 & \multicolumn{2}{|l|}{ S.D. dependent var } & 0.103335 \\
\hline S.E. of regression & 0.028088 & \multicolumn{2}{|l|}{ Akaike info criterion } & -4.150649 \\
\hline Sum squared resid & 0.048913 & \multicolumn{2}{|l|}{ Schwarz criterion } & -3.748951 \\
\hline Log likelihood & 168.6493 & \multicolumn{2}{|l|}{ Hannan-Quinn criter. } & -3.990255 \\
\hline F-statistic ${ }^{* * *}$ & 78.29907 & \multicolumn{2}{|l|}{ Durbin-Watson stat } & 1.507238 \\
\hline Prob(F-statistic) & 0.000000 & & & \\
\hline
\end{tabular}

Sumber: Analisis data primer, 2011

Keterangan: ${ }^{* * *}$ ) signifikan pada taraf $1 \%,{ }^{* *}$ ) signifikan pada taraf $5 \%,{ }^{*}$ ) signifikan pada taraf $10 \%$ 
Hasil analisis tabel 1 menunjukkan bahwa lahan, benih, Urea, SP36, $\mathrm{KCl}$, herbisida, pestisida, tenaga kerja, umur petani, pendidikan petani, dummy tipe luapan (D1,D2) secara bersama-sama berpengaruh sangat nyata terhadap produksi padi pada taraf kepercayaan 99\%. Hal ini ditunjukkan oleh nilai Prob (F-statistic) $<0,01(\alpha=1 \%)$.

Pengaruh lahan terhadap produksi padi sebesar 0.0342 (positif dan sangat nyata). Artinya, setiap penambahan luas lahan 1 persen (kondisi cetaris paribus) akan meningkatkan produksi padi sebesar 0.0342 persen. Hal ini menunjukkan bahwa produktifitas lahan pasang surut di Kabupaten Pontianak masih cukup baik. Jika produktifitas lahan mengalami penurunan maka pengaruh variable lahan akan negative. Apabila tingkat kesuburan lahan dapat terus ditingkatkan maka akan meningkatkan produktifitas sehingga pengaruh lahan akan terus positif terhadap produksi padi.

Penggunaan benih berpengaruh positif dan sangat nyata $(\alpha=1 \%)$ terhadap porudksi padi yang besarnya 0.1054 . Artinya setiap penambahan benih sebesar 1 persen (kondisi cetaris paribus) akan diikuti kenaikan produksi padi sebesar 0,1054 persen. Rata-rata penggunaan benih sebesar $38,54 \mathrm{~kg} / \mathrm{ha}$, hal ini menunjukkan bahwa penggunaan benih sudah cukup banyak (untuk varietas unggul), namun jika untuk varietas lokal tergolong sedang. Banyak sedikitnya penggunaan benih juga dipengaruhi oleh mutu benih (daya tumbuh). Pengaruh positif dari penggunaan benih menunjukkan bahwa mutu benih yang digunakan oleh petani relative baik. Jika mutu benih tidak baik, maka penambahan benih tidak akan diikuti peningkatan produksi, atau bahkan bisa berpengaruh negative.

Pupuk Urea mempunyai pengaruh nyata terhadap produksi sebesar 0.0576 . Artinya setiap kenaikan pupuk Urea sebesar 1 persen (kondisi cetaris paribus) akan menaikkan produktivitas tanaman padi sebesar 0.0576 persen. Rata-rata penggunaan Urea di tingkat petani sebesar $107,58 \mathrm{~kg} / \mathrm{ha}$. Dosis tersebut masih dibawah dosis anjuran yaitu $150-200$ $\mathrm{kg} / \mathrm{ha}$. Penambahan Urea masih perlu dilakukan hingga dosis rekomendasi, karena produksi masih akan bertambah.

Penggunaan herbisida berpengaruh positif dan sangat nyata $(\alpha=1 \%)$ terhadap produksi padi. Setiap bertambahnya penggunaan herbisida sebesar 1 persen (kondisi cetaris paribus), maka produksi padi akan meningkat 0.0825 persen. Rata-rata penggunaan herbisida sebesar 3,27 liter/ha, dosis tersebut masih dibawah anjuran yaitu 4-5 liter/ha sehingga masih perlu untuk ditambah sesuai dosis anjuran.

Tenaga kerja berpengaruh kurang nyata (pada $\alpha=10 \%$ ) dan positip terhadap produksi padi. Hal ini menunjukkan bahwa setiap peningkatan penggunaan tenaga kerja akan meningkatkan produksi padi. Koefisen regresi tenaga kerja sebesar 0.0165 artinya setiap peningkatan tenaga kerja sebesar 1 persen (kondisi cetaris paribus) akan menaikkan produksi sebesar 0.0165 persen. Rata-rata penggunaan tenaga kerja sebesar 83,97 HOK per hektar. Penambahan tenaga kerja masih dapat meningkatkan produktivitas, terutama tenaga kerja untuk pemeliharaan tanaman.

Umur petani berpengaruh sangat nyata yang besarnya 0.1043 , hal ini menunjukkan semakin bertambah umur petani pada batas tertentu (periode usia produktif) produksi padi semakin meningkat. Dengan semakin bertambahnya umur petani maka pengalaman dan keterampilan dalam usahatani padi akan semakin meningkat, sehingga akan berpengaruh positif terhadap produksi padi.

Usahatani padi di lahan pasang surut dilakukan di tiga tipe luapan, yaitu tipe A, tipe B, dan tipe C. Dummy variable tipe B (D1) sangat signifikan $(\alpha=1 \%)$ dan berpengaruh poisitif. Artinya budidaya padi di lahan pasang surut berbeda nyata dengan budidaya padi di lahan 
tipe luapan yang lain ( $\mathrm{A}$ dan $\mathrm{C}$ ). Tanda positif menunjukkan bahwa produksi padi di lahan tipe $B$ lebih tinggi dibanding dengan tipe luapan yang lain (A dan $C$ ).

\section{Perbedaaan Risiko Produksi Padi di Lahan Pasang Surut}

Untuk menganalisis beda resiko produksi dapat digunakan one-way anova. Data yang dianalisis adalah data risiko produksi (bukan data produksi), sehingga terlebih dahulu harus memperoleh data risiko produksi. Data risiko produksi diperoleh dengan metode Just and Pope (1974), yaitu mengestimasi fungsi produksi cobb-douglas dengan metode Non Linear Least Square (NLS) sehingga diperoleh disturbance error sebagai proxy dari resiko produksi. Fungsi produksi padi dalam bentuk NLS adalah sebagai berikut:

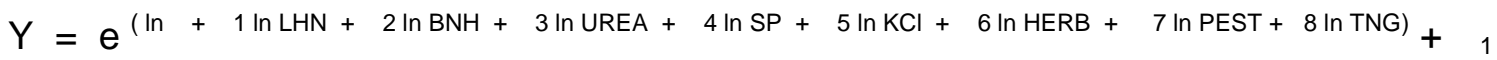

Dari regresi fungsi produksi padi dalam bentuk NLS tersebut akan diperoleh nilai disturbance error $\left(\varepsilon_{1}\right)$ yang merupakan nilai pendekatan dari resiko produksi yang selanjutnya dianalisis dengan one-way anova. Berdasarkan uji sidik ragam (Anova) terhadap resiko produksi pada tipe luapan $A, B$, dan $C$ menunjukkan nilai $F$ hitung 2,745 dengan nilai $\alpha=0,071(<0,1)$, artinya ada beda produksi antar tipe luapan.

Untuk mengetahui tipe luapan yang mempunyai perbedaan resiko produksi padi, maka dilakukan uji lanjut dengan menggunakan uji LSD (Least Significant Different). Adapun hasil uji lanjut LSD dapat dilihat pada tabel berikut:

Tabel 2. Hasil Uji Lanjut LSD (Least Significant Different) Beda Resiko Produksi Padi Pada berbagai Tipe Luapan Lahan Pasang Surut Kabupaten Pontianak Tahun 2011

\begin{tabular}{cccccc}
\hline & (I) TIPE_LUAPAN & (J) TIPE_LUAPAN & $(\mathrm{I}-\mathrm{J})$ Mean Difference & Std. Error & Sig. \\
\hline LSD & tipe luapan A & tipe luapan B & $-51.4238889^{*}$ & 22.4850213 & .025 \\
& tipe luapan C & -22.8985185 & 22.9486788 & .322 \\
tipe luapan B & tipe luapan A & $51.4238889^{*}$ & 22.4850213 & .025 \\
& tipe luapan C & 28.5253704 & 20.0061944 & .158 \\
tipe luapan C & tipe luapan A & 22.8985185 & 22.9486788 & .322 \\
& tipe luapan B & -28.5253704 & 20.0061944 & .158
\end{tabular}

Sumber: Analisis data primer, 2011

Besarnya risiko produksi terlihat dari nilai standar deviasi dimana secara berturut turut besarnya adalah 88,31 (tipe luapan A), 65,21 (tipe luapan B), dan 76,87 (tipe luapan C). Berdasarkan uji lanjut LSD diketahui bahwa risiko produksi pada tipe $A$ berbeda dengan tipe $\mathrm{B}$, artinya resiko produksi tipe $\mathrm{B}$ lebih rendah dibanding tipe A. Sedangkan resiko produksi tipe $\mathrm{C}$ tidak berbeda nyata dengan tipe $\mathrm{A}$ dan tipe $\mathrm{B}$.

Berdasarkan uraian di atas dapat diketahui bahwa risiko produksi pada tipe A lebih tinggi dibanding tipe B. Hal ini disebabkan lahan tipe A selalu terluapi air pasang, baik pasang besar maupun pasang kecil, sehingga rawan terjadinya interusi air asin. Selain itu pada kondisi drainase yang buruk pada tipe $A$ akan cenderung lebih lama tergenang air baik karena air pasang maupun karena hujan. Berbeda dengan tipe B, merupakan lahan yang hanya terluapi oleh pasang besar. Pada tipe B ketersediaan air akan lebih stabil karena 
disupply dari air pasang besar dan air hujan, selain itu juga resiko interusi air asin sangat kecil sehingga resikonya lebih rendah.

\section{Faktor-Faktor yang Mempengaruhi Risiko Produksi Padi di Lahan Pasang Surut.}

Langkah pertama untuk menganalisis risiko produksi adalah mengestimasi fungsi produksi cobb-douglas dengan metode Non Linear Least Square (NLS) sehingga diperoleh disturbance error $\left(\varepsilon_{1}\right)$ sebagai proxy resiko produksi. Selanjutnya distrubance error/resiko produksi tersebut di regress terhadap variabel bebas dengan metode Ordinary Least Square/OLS, sehingga asumsi klasik harus terpenuhi.

Sebelum melakukan uji statistik terhadap hasil regresi, terlebih dahulu dilakukan uji multicollinierity. Untuk mengetahui adanya gejala multicollinierity dapat diamati dari nilai Variance Inflation Factor (VIF). Hasil analisis menunjukkan bahwa nilai VIF untuk semua variabel bernilai di bawah 10, hal ini menunjukkan bahwa tidak ada gejala multicollinierity.

Selanjutnya dilakukan uji gejala heteroscedasticity dengan menggunakan beberapa uji untuk diperbandingkan. Untuk mengetahui adanya gejala heteroscedasticity dapat ketahui dari beberapa uji yaitu White, Breusch-Pagan-Godfrey, Harvey, dan Glejser. Hasil analisis menunjukkan bahwa terdapat gejala heteroscedasticity. Untuk mengatasi masalah tersebut digunakan metode White heteroskedasticity-consistent standard errors \& covariance. Hasil analisis yang bebas gejala multicolinearity dan heteroscedasticity adalah sebagai berikut:

Tabel 3. Faktor-faktor yang mempengaruhi produksi padi di lahan pasang surut Kabupaten Pontianak (bebas gejala multicolinearity dan heteroscedasticity)

\begin{tabular}{lrlrr}
\hline \multicolumn{1}{c}{ Variable } & Coefficient & Std. Error & t-Statistic & Prob. \\
& & & & \\
\hline \hline C & 5.756931 & 6.194137 & 0.929416 & 0.3562 \\
LHN $^{*}$ & -1.112598 & 0.662868 & -1.678461 & $\mathbf{0 . 0 9 8 1}$ \\
BNH $^{*}$ & -1.724375 & 0.879907 & -1.959724 & 0.0544 \\
UREA & 0.893193 & 0.815160 & 1.095728 & 0.2773 \\
SP & -0.005492 & 0.101609 & -0.054046 & 0.9571 \\
KCL & 0.025548 & 0.078697 & 0.324638 & 0.7465 \\
HERB & 0.204926 & 0.893021 & 0.229475 & 0.8192 \\
PEST & -0.113159 & 0.194837 & -0.580790 & 0.5634 \\
TNG & 0.217140 & 0.433788 & 0.500566 & 0.6184 \\
PDDK & 0.509670 & 0.419662 & 1.214476 & 0.2290 \\
UMUR & -0.632205 & 1.579554 & -0.400243 & 0.6903 \\
\hline \hline R-squared & 0.232466 & Mean dependent var & & 3.691333 \\
Adjusted R-squared & 0.045267 & S.D. dependent var & & 1.340114 \\
S.E. of regression & 1.309431 & Akaike info criterion & & 3.511791 \\
Sum squared resid & 109.7351 & Schwarz criterion & & 3.851689 \\
Log likelihood & -120.6922 & Hannan-Quinn criter. & & 3.647509 \\
F-statistic & 2.056420 & Durbin-Watson stat & & 1.956474 \\
Prob(F-statistic) & 0.033549 & & \\
\hline \hline
\end{tabular}

Sumber: Analisis data primer, 2011

Keterangan::. ${ }^{* * *}$ ) signifikan pada taraf $1 \%,{ }^{* *}$ ) signifikan pada taraf $5 \%,{ }^{*}$ ) signifikan pada taraf $10 \%$. 
Berdasarkan nilai koefisien determinasi $\left(R^{2}\right)$ dapat diketahui bahwa variabel bebas yang dianalisis dapat menjelaskan $23,25 \%$ terhadap variabel resiko produksi padi. Variabel produksi padi yang tidak dapat dijelaskan oleh variabel-variabel indepeden (bebas) tersebut sebesar $76,75 \%$. Hal ini disebabkan oleh faktor lain yang tidak masuk dalam model seperti resiko kekeringan, kebanjiran, interusi air laut, resiko pasar, kandungan pirit dan variable lain yang sulit untuk diukur.

Nilai F-statistik sebesar 2.056 dengan nilai Prob (F-statistic) $<0,05(\alpha=5 \%)$. Artinya variabel luas lahan, benih, Urea, SP36, $\mathrm{KCl}$, jumlah herbisida, jumlah pestisida, tenaga kerja, umur petani, pendidikan petani, secara bersama-sama berpengaruh nyata terhadap risiko produksi padi pada taraf kepercayaan 95\%.

Hasil analisis tabel 3 terlihat bahwa lahan berpengaruh nyata yang besarnya 1.1126, artinya setiap penambahan luas lahan sebesar 1 persen akan menurunkan risiko produksi padi sebesar 1.1126 persen. Dengan penambahan lahan sampai batas tertentu akan meningkatkan skala usaha, produksi, dan efisiensi dalam usahatani, sehingga akan menurunkan risiko produksi padi di pasang surut.

Penggunaan benih berpengaruh negatif dan nyata sebesar -1.7244 , artinya setiap penambahan benih sebesar 1 persen akan diikuti penurunan risiko produksi padi sebesar 1.7244 persen. Paningkatan penggunaan benih yang bermutu sampai pada batas tertentu akan menambah populasi tanaman, sehingga dapat meningkatkan produktifitas dan akhirnya dapat menurunkan risiko produksi.

\section{KESIMPULAN DAN SARAN}

\section{Kesimpulan}

1. Faktor-faktor yang mempengaruhi produksi padi adalah lahan, benih, Urea, herbisida, tenaga kerja, umur petani, dan dummy tipe luapan B. Setiap penambahan luas lahan $1 \%$ akan menambah produksi padi $0.0342 \%$. Setiap penambahan benih $1 \%$ akan diikuti kenaikan produksi padi $0,1054 \%$. Setiap kenaikan Urea $1 \%$ akan menaikkan produksi padi $0.0576 \%$. Setiap bertambahnya herbisida $1 \%$ akan diikuti peningkatan produksi padi $0.0825 \%$. Setiap peningkatan tenaga kerja \% akan menaikkan produksi $0.0165 \%$. Semakin bertambah umur petani sampai batas tertentu (periode usia produktif) produksi padi semakin meningkat.

2. Berdasarkan uji LSD, resiko produksi pada tipe $B$ lebih rendah dibanding tipe $A$. Sedangkan risiko produksi tipe $\mathrm{C}$ tidak berbeda dengan tipe A dan tipe B. Berdasarkan nilai standar deviasi, risiko produksi paling tinggi pada tipe $A$ diikuti tipe $C$, dan tipe $B$, atau dengan kata lain tipe $B$ mempunyai resiko produksi paling rendah.

3. Faktor-faktor yang mempengaruhi risiko produksi padi adalah lahan dan benih dengan pengaruh negatif. Setiap penambahan lahan 1\% akan menurunkan risiko produksi $1.1126 \%$. Setiap penambahan benih $1 \%$ akan menurunkan risiko produksi $1.72 \%$.

\section{Saran}

1. UntuK mengurangi risiko produksi di lahan pasang surut perlu melakukan olah tanah secara minimum/minimum tillage, menggunakan varietas yang sesuai (cisadane, IR 64, Barito, Ciherang), dosis pupuk yang tepat (Urea $150 \mathrm{~kg} / \mathrm{hg}$, SP36 $100 \mathrm{~kg} / \mathrm{ha}, \mathrm{KCl} 75$ $\mathrm{kg} / \mathrm{ha}$ ), perbaikan tata air makro dan tata air mikro, dan penerapan SLPHT. 
2. Selain teknologi, untuk keberhasilan dan keberlanjutan usahatani di lahan pasang surut juga perlu ditingkatkan kemampuan SDM dan rekayasa kelembagaan yang efektif dan efisien, terutama kelompok tani dan P3A, lembaga penyuluhan, serta lembaga penyediaan sarana produksi dan pemasaran hasil.

\section{DAFTAR PUSTAKA}

Gujarati, D., 1997. Dasar-Dasar Ekonometrika Jilid 1. Penerbit Erlangga Jakarta.

Hermawan, Asep. 2005. Penelitian Bisnis: Paradigma Kuantitatif. PT. Grasindo. Jakarta

Just, R.E, dan R.D. Pope, 1974. On The Relationship of Input Decision and Risk. Roumasset, J.A, Boussard, J.M, Singh, I. (eds). Risk Uncertainty and Agricultural Development. Agricultural Development Council. New York. USA : 178-197.

Kay, R.D., 1981. Farm Management Planing Control and Implementation. International Student Edition. Mc Graw Hill International Book Company. New York.

Pasaribu, Amudi. 1983. Pengantar Statistik. Ghalia Indonesia. Jakarta Timur.

Pindyck,R.S, dan D.L Rubenfeld, 2001. Microeconomics. Prentice Hall International.Inc.

Supranto, Johanes. 1983. Ekonometrika. Lembaga Penerbit Fakultas Ekonomi Universitas Indonesia. Jakarta

Surachmad, W, 1988. Pengantar Penelitian Ilmiah, Dasar, Metode, Teknik. Tarsito. Bandung.

Suratno dan L. Arsyad. 1988. Ekonomi Mikro. BPFE Universitas Gadjah Mada. Yogyakarta.

Widodo, Sri. 2006. Strategi Mengatasi Rawan Pangan : 1-7. Seminar Nasional Forum Komunikasi Kebijakan \& Pusat Studi Asia Pasifik-UGM. Yogyakarta 